Historic, Archive Document

Do not assume content reflects current scientific knowledge, policies, or practices. 

62,43

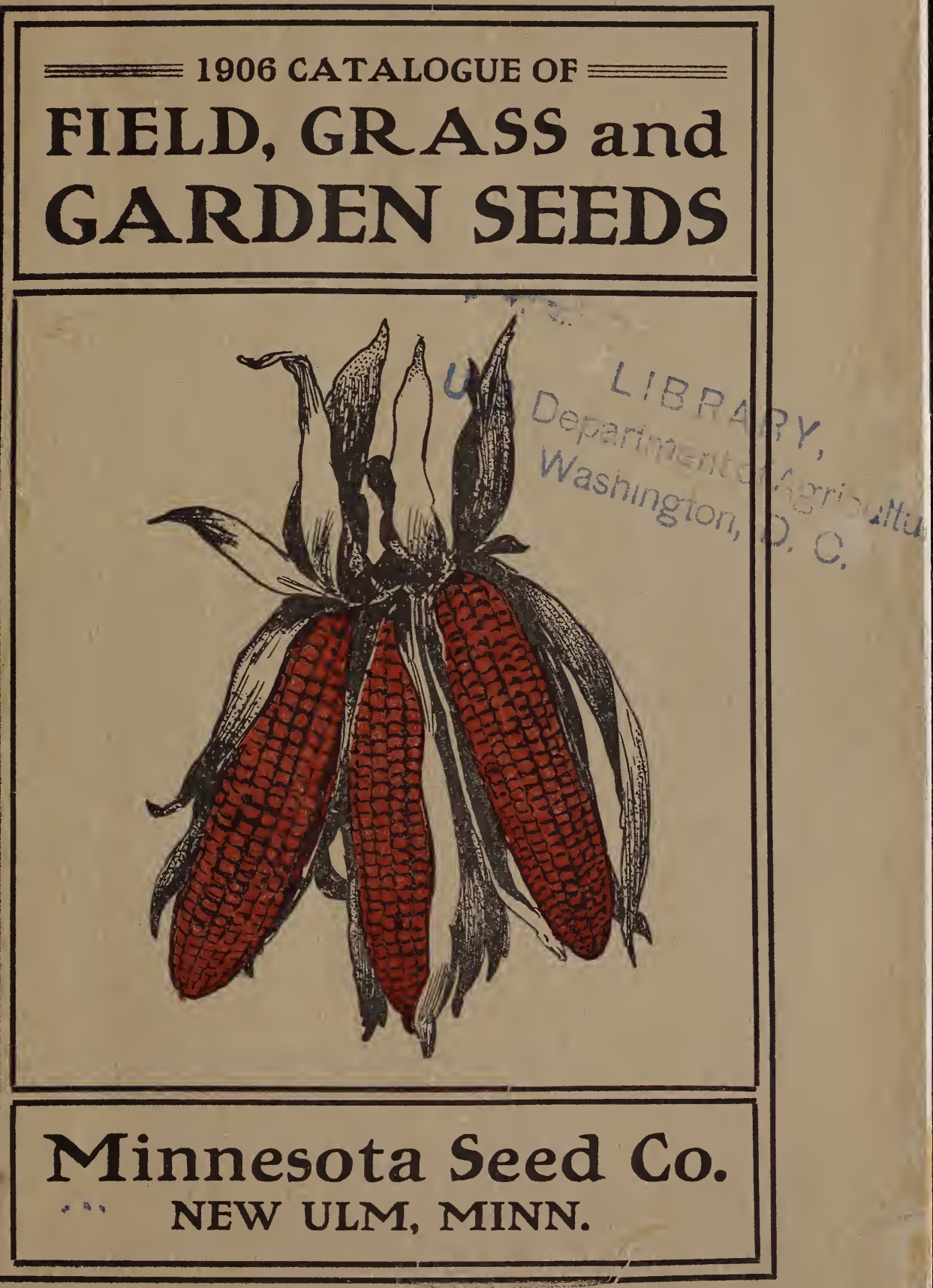





\section{To The Public}

世. \%

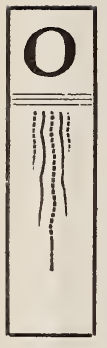

UR CATALOGUE is presented to you under a new name this year The Minnesota Seed Co., (as successors to Fred Meier, Sleepy Eye, Minn. Our location is New Ulm, Minn. There is pleasure in progress, and it gives the writor a keen pleasure io have achieved the purpose which has been his aim for several years, to own an equipment with which it would be possible to take care of a growing business, to solve the problem of handling large quantities of seed corn in such a way as would make it FIneT Class S'EED, not only in germination but in producing qualities. Our new building, which we show on another page, is the most complete and largest building for this purpose in the country. We own hundreds of acres of land in the best portions of the state and will make it our aim to supply the best seed our soil can produce. We have here a great variation in soil and with our short seasons, we can produce seed which is suiter to any section. Our assertion is substantiated by our sales.

Our few illustrations taken from actual objects look rather insignificant beside the catalogues of many Seermen, which are filler with impossible wood cuts and descriptions of seeds with world breaking records, none of which are capable of producing such records in the hands of the purchaser.

We hope to put our buasts in the quality of our seeds, where we trust our customers will have no trouble to find them. 


\section{Seed Corn.}

The past season has shown that the corn belt is making rapid strides northward. Southern and central Minnesota, Wisconsin and North Dakota must take up the work of systematic corn growing, procuring varieties which will make profitable yields. The question of improving corn by breeding has proven itself to those who have triedit, and this work is being taken up in all sections, Our superior equipment along this line places us in a position to do this work which the ordinary grower has not time or inclination to do. Corn produced in this way is worth many times it's original cost to the purchaser. In a recent test by the government, corn which was dried by artificial heat produced 16 bushels more per acre than did air dried seed on the same field.

This season the grades of corn from our western states are bringing the highest price on the market, being more sound and better quality than corn from the central states. I his proves our contention which was that it is more profitable to grow varieties of corn which will mature and make fair yields than grow larger and later varleties which too frequently fail to mature, in which case the corn is of considerable less va ne.

We would advise famers who hesitate buying our seed corn to thoroughly test their own air-dried corn and note the difference in the ritality of that and seed properly cured

The business of seed corn growing has enormously increased in the corn belt south of us. We trust the farmers will ive us their support by at least testing the merits of our seed as compared to the home grown.

\section{PRICES}

Our Prices. While our prices may seem high to the man who has not tried our seed, and can buy seed corn from a neighbor for less money (Warranted every kernel to grow?) if he will just stop to consider the cost of handling corn our way will find the price reasonable and the fact that one bushel will plant siven or eight acres makes the cost of seed but a trifie per acre.

Our prices are for regular stock shelled and two bushels in a bag F. O. B. our station. To those who wish to buy any of the varieties offered in the ear we will supply such corn at an additional price of 25 cents per bushel to pay for added cost of selecting and handling. Orders for such seed will be filled up to April 15th after which all stock will be shelled.

Send 18 cts. extra for bags for each two bushels ordered. We will give a discount of 2 per cent on 10 bushel orders, 5 percent on 25 bushels and 10 per cent on 50 bushel orders.

In ordering state expressly how you want seed shipped, giving route if you have any preference. Wr te plainly your name and address. Remit by draft, money order, registered letter or express order. 


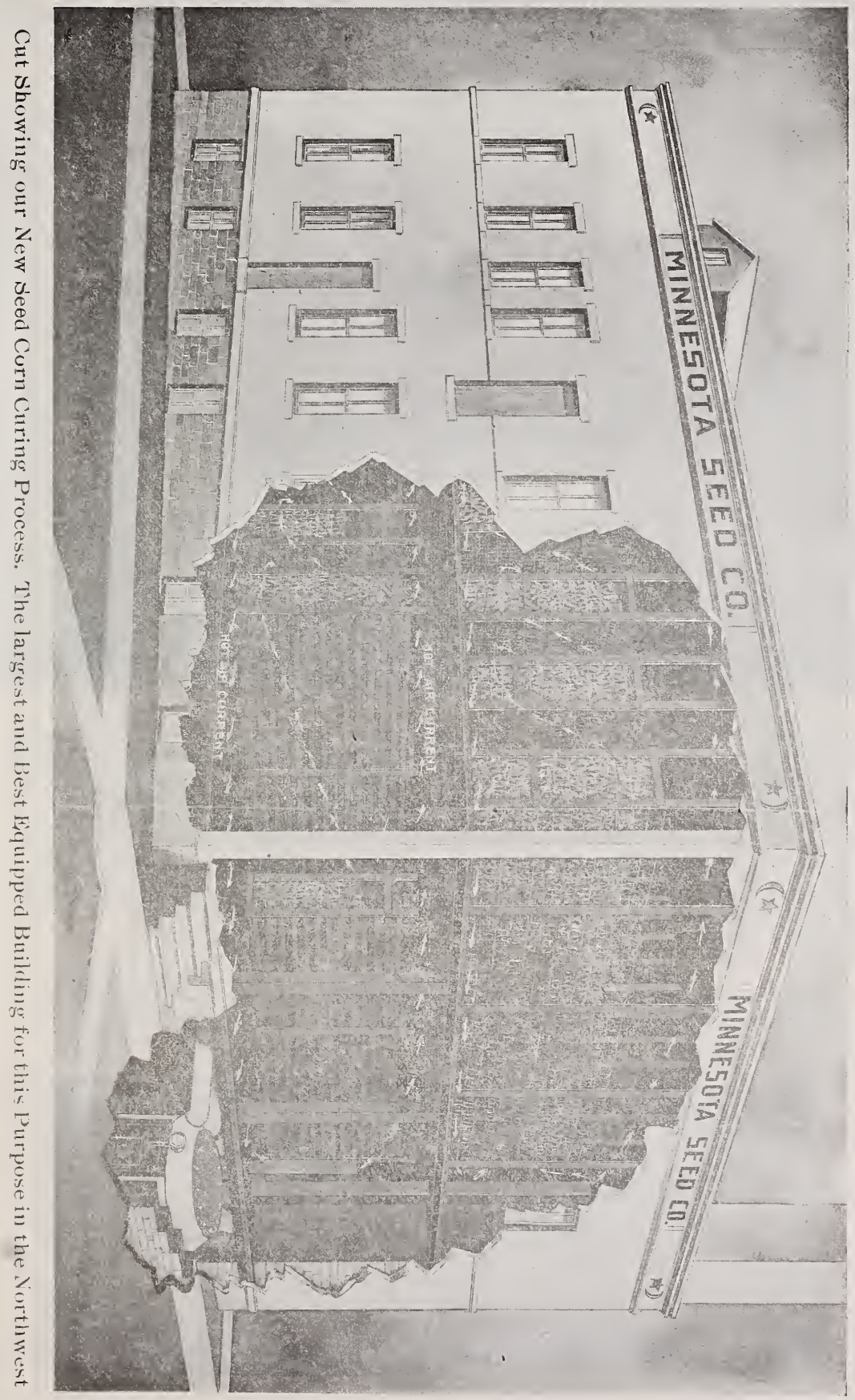




\title{
Practical Corn Breeding
}

\author{
By Fred Meier at the Madison, Wis. Convention
}

The subject of plant breeding has had an impetus during the past half decade such as it has in no previous period, and I think more has been accomplished in this time than in any quarter of a century in the history of the country. A few years ago it was an unusuil occurrence to find an article on the subject of agriculture in any but the agricultural papers. Today all the leading general magazines and daily newspapers are devoting more space to this subject than to any other one subject. Besides this. some of the ablest men that we have are editing newspapers devoted entirely to this subject, and why should not this be so? Is not agriculture the foundation of all that is material? When we think of the step between the thorn apple and the large, luscious, palatable apple that we are growing today. the difference between the wild grape and the domesticated ones that are now producing the wealth of the globe. Or, again, the chasm between the maize plant that the Indians had when this continent was first discovered by the Europeans and the corniplant that is now yielding an amount of deep grained ears, containing arge percentage of eitheroil or starch at the will of the farmer, with a yield per acre which seems limited only by the skill of the grower. It would seem to me this ought to lead to still greater efforts and it is beyond the ken of man to know where the limit in the production per acre will go. To show that there is much need of improvement along this line in a general way, I will quote some figures taken from the report of the secretary of agriculture:

The total yield in corn since 1889 will average nuarly two billion bushels per year. Our average yield in 1889 was twenty-seven bushel per acre, and only in one year since then has the yield exceeded this. In 1896 the average yield was twenty-eight and twotenths bushels. Our acreage has risen from the $\because 0,00 ;, 000$ mark up to $94,000,000$ acres. In 1902 and in this year the total yieid exceeded all others, and the value of the product on the farm was more than $\$ 1,000,000,600$ and was equal in value the whole of the wheat, oats, rye, barley, buckwheat, potato and fia $x$ crops ccmbined.

For all this there is yet room for improvement as the average yield in this year was only 26.8 bushel per acre.

There is another lesson to be learned in connection with these statistics. The average yield in the corn states of Ohio, Indiana, Illinois. Iowa, Nebraska, Kansas and Missouri was only $27.7 \mathrm{~s}$ bushels, while that of the New England states is 36.48 . This in view of the fact that we westerners are taught. that the soil in those states is run out. speaks well for the thrifty New Englander.

Coming back to our section, Minnesota and Wisconsin are in a group of states in which the average is only slightly above the general average, or $2 \% .6$ bushels per acre. This is only about one-half of what the yield could be. did each farmer use a limited amount of energy with a grain of good sense and rigilance $t$ hrown in. Some good farmers located on favorable corn soil raise from $\% 0$ to 100 bushels per acre. The secret of getting these yields lies in making each stalk bear a good sized. sound ear. Just by way of proof that such yields are possible, a field planted to corn in hills the usual distance apart. yielding three pounds of corn to the hill, would yield 15.5 bushels per acre.

It is a well known fact that the influences of an increased area of timber has a decided effect as to the amount of precipitation, likewise an increased acreage of corn, has a similar effect upon climate. You will notice that only in rare instances does a section of the country where corn is the main crop suffer from the effect of a drouth; thus does a corn crop, which is the most profitable that a farmer can grow, not only insure itself, but is practically a guarantee to his small grains. Besides, this corn is not unly a life sustaining product but can be converted into meat. starch, sugar, or into many other products too numerous to mention. Futhermore, corn will leave your soil in better condition for the nther crops following than any othercrop, with the possible cxception of clover. Putting these two together you have a combiuation that is hard to beat.

In this northwestern section of the country corn ought to form a more important part in crop relation than it does at present. It has been proven repeatedly in our wheat growing section that corn is a very paying crop, as a field will produce as much wheat the two yeurs following a crop of corn as will a similar field planted to wheat for three consecutive years.

Returning to the subject of corn improvement, it has been demonstrated, more par- 
ticularly in stock of all kinds, that where a man has an ideal he can by persistency, pahis object. Toillustrate: See how the people who have had in mind the production of the best beef cattle with tne least percentage of loss, produced in the most economical way, have built up strains of Shor horn, Herefords and other breeds of cattle; stock which we need not be ashamed of. were all the planets inhabited and did their inhabitants come to view our efforts. In horses the limitations seem only as a man is satisfied with his efforts; does he wish to produce a drafter with strength, endurance and beauty he accomplishes his purpose; if he turns this efforts tu speed like results crown his efforts. But still we find some who are dissatisfied. They want an animal with other qualities than those alrealy mentioned. Some observing man who has profited by others' experience conceives the idea of crossing the horse and idonkey. I he risult. a mule, an animal admirably adapted to the uses for which it was intended.

Summing up the results accomplished undercertain conditions with the corn plant, we are forced to the opinion that the causes of our low yields in corn are not so much the quality of the plant we already have as it is the manner and conditions under which it is grown by most farmers.

To develop an animal to it's fullest degree of perfection, it must have proper care and proper feed. The same is true of plant life. To fully develop a stalk or a field of corn. it is necessary that there bo the proper kind of nourishment in the soil in which it is to be planted.

It might be well to call attention to the fact that the corn plant is ous of the fitw plants capable of drawing nourishment directly from fertilizer in the form of barnyard manure, it being necessary to undergo a chemical change before being available to most plants. That the habits of the plant be understood so that it can be tilled in amanner that will stimulate it to put forth it's very best efforts and above all it is necessary that the seed used be capable of producing such a product as is required. Ii you will but follow the simpler rules in this matter you will as. tonish yourself with the results obtained.

If you were to buy some stock with which to start a herd, you would, of course. buy those with a pedigree. This pedigree is a guarantee to you that these animals are the descendants of sires and dams capable of producing animals of a certain quality. This same principle can be made to apply to plant life as well.

The first essential point in making a begin. ning in corn improvement is to procure the best seed of the best variety adapted to that poriton of the country in which you live. and suited to the purpose for which you want it whether it be for stock feeding, for market or for manufacturing purposes, Plant this seed on the best soil at a distance to prevent pollen from other fields blowiug in, giving it the best possible cultivation. If you have been faithful in your work you will be gratinied by the results. But now your work has only fairly begun. After the corn has about reached it's maturity you must go to the field and pick ears from vigorous, healthy stalks bearing nearest your ideal ears. Such ears should be cylindrical in shape, that is. having nearly equal circumference the full length of the ear, being well filled at both the tip and butt; cob of uniform color, the rows of kernels being as straight as possible, the kernel should gradually broaden from the point to the top. as this shaped kernel allows of the least waste of space between the rows and gives a larger percentage of shelled corn

After making your selections you will hav- accomplished practica'ly all you can do in the first season's work; having selected the early maturing ears you have shortened the general time for maturing (and taking the past two seasons into consideratson that is a very material point to be gained.) By selecting the best ears those most ideal in shape, as you will see later, among these will be found some that are capable of reproducing themselves.

Fur the second year. secure a plot of ground isolated from your other corn fields, making the rows no longer than can be planted from one ear of corn. Select the best ears from those picked in your field the autumn before planting each row with a separate ear and nimbering the rows. After the shoots that form the ears begin to show and before the pollen falls on the silks, pass through the plot, removing the tassel from the stalks that do not give promise of developing a vigorous, good sized ear. As pollen falling on the silk is what fertilizes an ear and produces the lrernels. removing the tassels from the weak stalks removes the danger of these weakening the vigorous and healthy ears, and yet by leaving these in the field to bear as good an ear as possible, giving you a basis on which to figure as to which are capable of the heaviest production. After this plot has reached maturity or if you wish to further select this corn for earliness, continue to selet the best. earliest maturing ears, $1 \mathrm{ag}$ ging each ear with the number in which it grew. After making these selections leave remainder of the corn in this breeding plot until thoroughly ripened. In examining these rows separately you will notice that some of the rows have less barren stalks, have a stronger stalk and altogether have made a better yield. After harvesting each row sep. aritely you will be in a position to know which of the ears selected earlier in the season are the ones you want for your next year's breeding plot. Selecting your seed for general field planting from the best produc ing rows, discarding those of low yield.

While much improvement can be accomplished by this method, yet there remains the possibility of the best yielding rows, being fertilized with pollen from the lesser yielding rows, This drawback is gradually eliminated as the seed of your breeding plot becomes of a higher staudard and it is only after long and persistent effort along this line that your work will begin to show, and you wiil have accomplished something that is of real worth to the community.

There is another method of corn improvement that I have not spoken of as yet. This constitutes of hybridizing. Taking two standard varieties, each having some of the properties you want and planting these in alternate rows, removing all the tassels in the rows of one variety. This allows this variety to be fertilized with the pollen from the other variety. In this way a positive cross or hybrid is the result.

Selecting seed from the detasseled row you will find a great variety of types of corn, few if any; haying any resemblance to either of the parent varieties, and likewise few being near the type you may have in mind, and the few resembling this type often prove a disappointment, from the fact that on being planted the following year they do not retain their type or do not prove good producer's. It is only after continued and untiring efforts that results are obtained by this method. It may be necessary to try crossing quite a nuwber of different varieties before a hybrid is found which may be of real worth. It must be horne in mind that to develop a hybrid all essentials must be farorable: thus an adverse season may undo all that you have spent several years in acconiplishing. 


\section{Golden Yellow Dent}

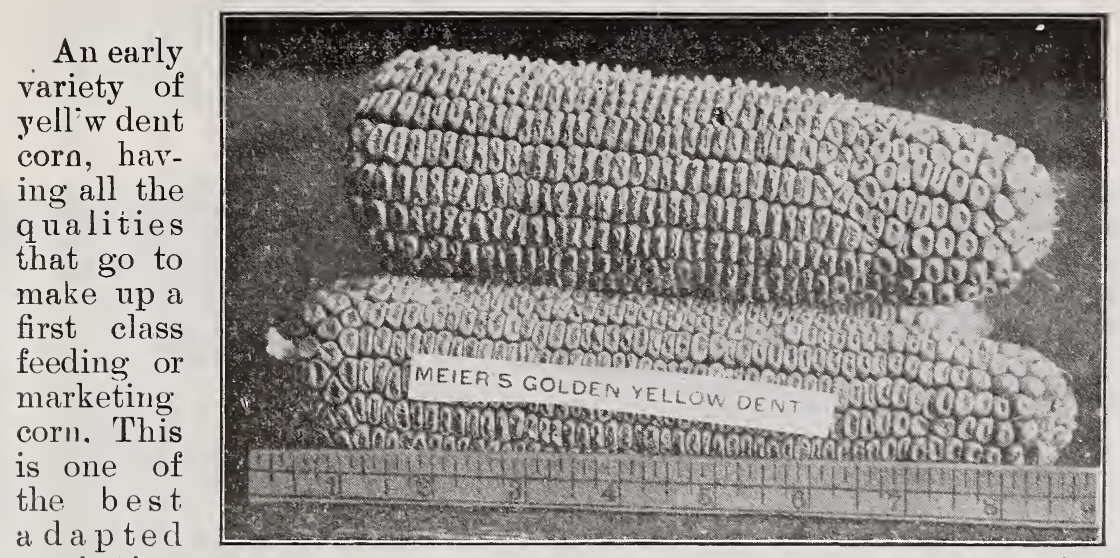

varieties

for sections as far north as central Minnesota and Wisconsin, altho. several fields ripened in the Red River Valley in 1905. While the deep kernel and general appearance of this corn would lead one to think it was not an early corn, yet in the eight years we have grown this corn it has never failed to mature and furnish a good yield. It has a deep kernel of a rich golden color, a small cob, medium sized ears. $6 \frac{1}{2}$ to $7 \frac{1}{2}$ inches in circumference; an average of 8 inches in length, the top of the kernels being somewhat rough. The stalks grow to good height. for haudling with binder and makes first class fodder. 'This corn will hold its type under adverse conditions, and make a good yield. with large percentage of shelled corn. Price per bushel (bags extra).\$2.00

\section{Minnesota No. 13 Dent}

This variety of Yellow Dent corn was origmated and improved by the State Experimental Station. It has been bred with a view of eliminating barren stalks and making each stalk produce an average sized ear. It is an early hardy corn, smoothe kernels set compactly on cob with no waste space between rows. The average length of ears is 8 inches with from 16 to 20 rows of kernels. Stalks grow to fair height and ears sufficient distance from ground to handle conveniently. This corn is grown from seed obtained directly from the station and has made a remarkably good showing in yields in the past. Fields on our own farms having showu an average yield of 65 bushels per acre. Price per bushel (bags extra)......\$2.00

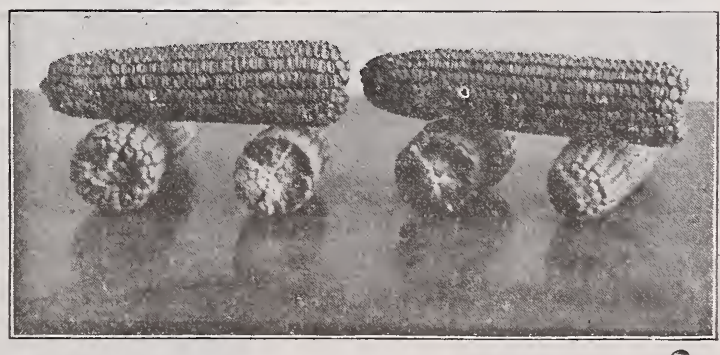




\section{CHOICE YELLOW DENT}

A variety of Yellow Dent resembling the Golden Yellow, but having a larger ear, somewhat taller stalk, requiring longer time to mature, and con tains large percentage of food elements. For those having a favorable corn soil this variety will be found valuable as it will bring good yields on such soils. It has been carefully selected, and will be found a good yielder suitable for sections not too far north. Price per bushel (bags extra) $\ldots \ldots \ldots \ldots \$ 2.00$

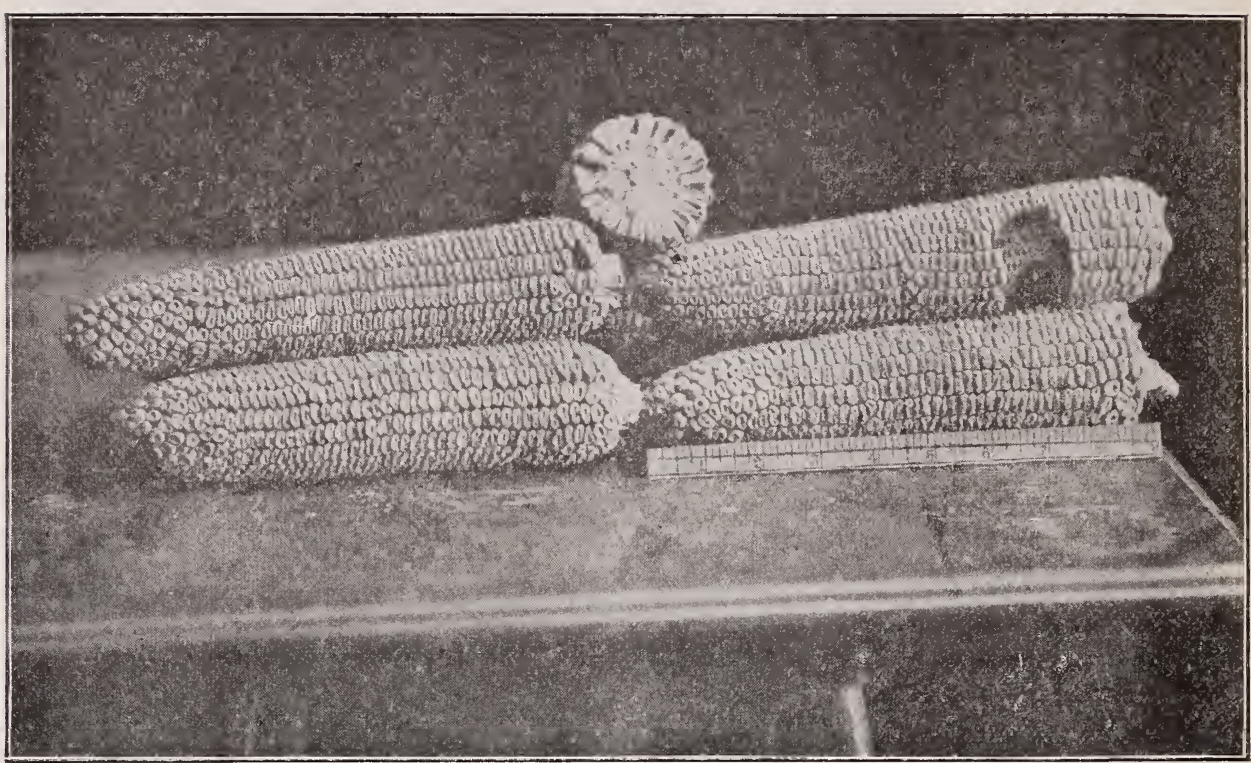

\section{Choice White Dent}

\section{A Variety of White Dent Corn of a Uniform Type.}

It is more popular in some sections than the yellow varieties, some claining that on light soils it will make better yields. We do not think this true, however Choice White Dent has always given good results. Its kernels are not quite as deep as those of the yellow varieties but in yields it compares favorably. This corn has proven itseli a goud yielder. Stalks of this variety are good height. Ears $21 \%$ to 3 feet from the ground. Very small percentage of barren stalks. Price per bushel (bags extra) ...........\$2.00

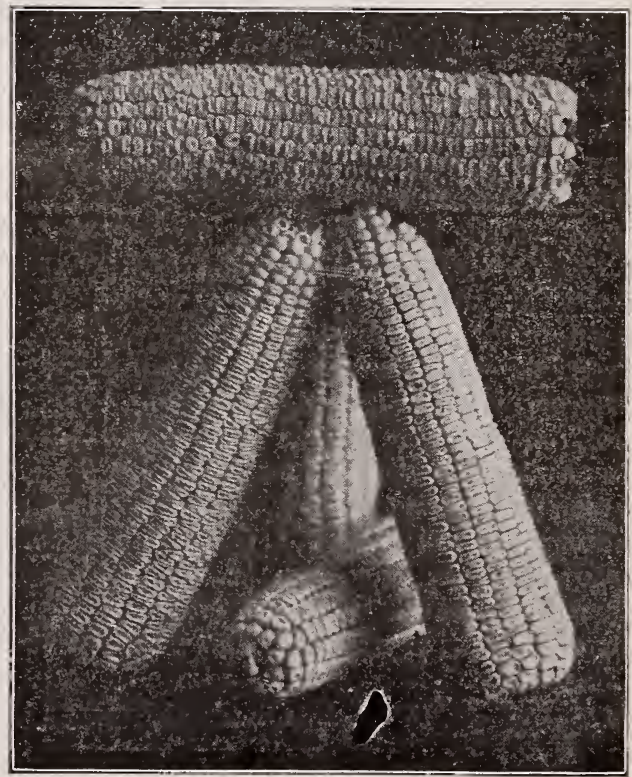




\section{North- western Dent}

The most popular corn in the Northwest today. If you want a variety which will grow on any kind of soil Northwestern Dent will not disappoint you.

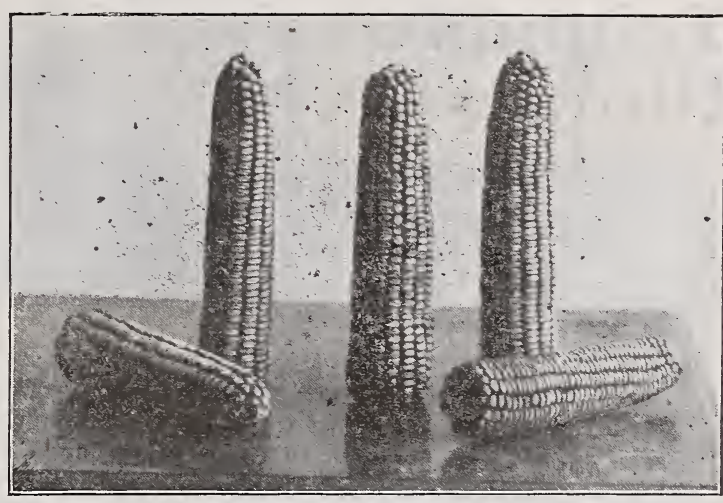

After a number of years of trial of this variety we contend that it is and will continue to be for some time to come one of the best varieties to grow in central and western Minnesota and South Dakota and in all parts of North Dakota, in fact wherever a hardy variety of corn is needed. Should the adverse seasons continue it will be grown to advantage in more southern sections. This corn is a cross of the Blood Butcher Dent and some variety of Flint. It has some characteristics of both Dent and Flint corn. It has the hardness and quick growing qualities of the Flint, and the Dent cllaracteristic in form. shape of ear and stalk.

On page 4 will be found a cut of ears of this corn as used in nur breeding plot. Recognizing the good qualities of this corn we are making a special effort to improve it for earliness, yielding quality and type. The are growing this corn with special view of supplying the need of a hardy and early corn in the northwest and have supplied some of the best growers in seasons past to their entire satisfaction.

Average length of ears 9 inches, average circumference $6 \frac{1}{2}$ inches, from 12 to 20 rows of kernels. This corn does not sucker $10 \mathrm{a} y$ great extent and can be handled to advantage with a binder. Price per bushel (bags extra) ....................\$2.00

\section{Yellow and White Dent}

We have a sma11 stock of both Yellow and White Dent Corn, grown here in the county. While it is selected yet it is not grown with special care for seed, it is cured in the same way our regular seed is, and a good germinating quality as regular stock. Price per bushel (bags extra).......\$1.50

\section{Mercer Flint}

A bright yellow Flint resembling Triumph. Somewhat shorter in stalk, smaller ears and kernels. Possibly a little earlier maturingr. Price per bushel (bags extra)........\$2.00

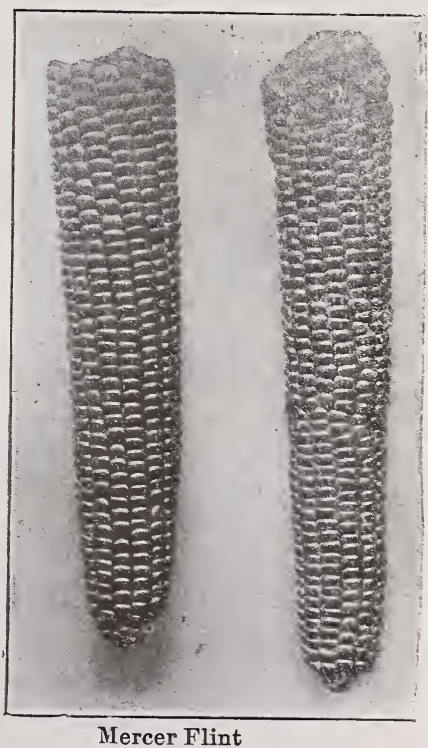




\section{Triumph Flint...}

A variety of Flint, bright yellow in color, with average length of ears about 12 inches and with from 14 to 16 rows of kernels. This is the largest and best yielding of the flint

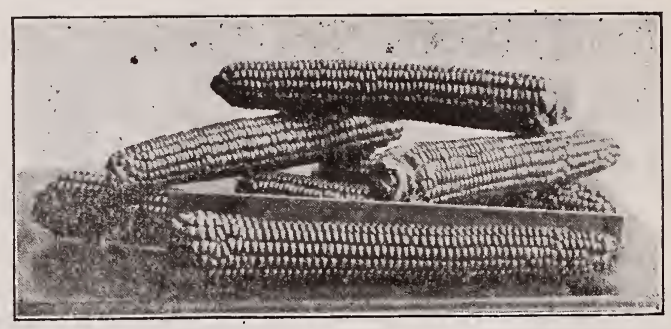
varieties, both in ears and the amount of fodder produced. It grows tall enough to be harvested with a corn binder and will produce a surprising a mount of fodder to the acre. Like the Northwestern Dent it is claimed for it that seed grown under favorable ccnditions will vield much heavier in the northern sections than will seed of the same variety grown there. In sections of the country where the seasons are short or where an early feeding corn is wanted this variety will be found the hardiest and most productive. It will mature from two to three weeks earlier than the Dent varieties.

While this corn suckers some it can be handled with a binder without trouble and all ears and fodder saved. Price per bushel (bags extra)... \$2.00

\section{FODDER CORN}

After an exhaustive test by the Minnesota Experimental station and the largest growers of fodder corn it has been proven that an early dent corn will produce more feed per acre than will the southern grown corn which has been used extensively heretofore, for fodder purposes. The northeris grown corn producing smaller stalks and often small ears, which makes excellent feed. This seed is kiln dried, like our regular seed corn and will be found to have large percentage of germinstion. From $1 / 2$ to 1 bushel per acre is required. Price per bushel (bags extra) ....................... \$1.00

\section{Flint Fodder Corn}

Many people prefer a Flint Corn for fodder as it requires less seed and grows a finer stalk, and makes a more rapid growth. Can be sown as late as

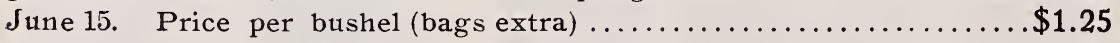

\section{Stowell's Evergreen Sweet Corn}

A Sweet Corn that is used extensively by market gardeners and by dairymen for fodder purposes. It will produce more and better fodder for milch cows per acre than any other forage plant. Price per peck (bags extra) 75c

Price per bushel ......................... \$2.25

\section{Southern Grown Fodder Corn}

Some dealers sell this under various names, Giant, Elephant, Red Cob, etc. We offer Genuine Southern Grown either White or Yellow Fodder. This will make extra large growth of stalks unless planted very thickly. Price per

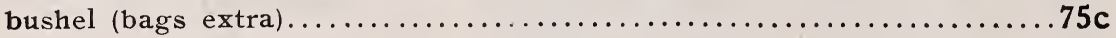




\section{Seed Wheat Minnesota No. 169 Wheat}

Our most successful wheat in Minnesota, No. 169 Blue Stem as is shown by the table following. Our supply of this wheat is of excellent quality.

On the next pige will be found a statement of the manner of originating this wheat, and a record of its producing ability. This was taken from a bulletin sent out by the Experimental station and written by Prof. IV. M. Hays. It has been proven beyond a doubt that this is the best yielding variety of wheat grown in the state at the present time.

In wheat as well as other seeds the ability to produce large yields should be taken into consideration in getting a new strain of seed. Price per bushel (bags extra) \$1.35

Write for prices on larger lots.

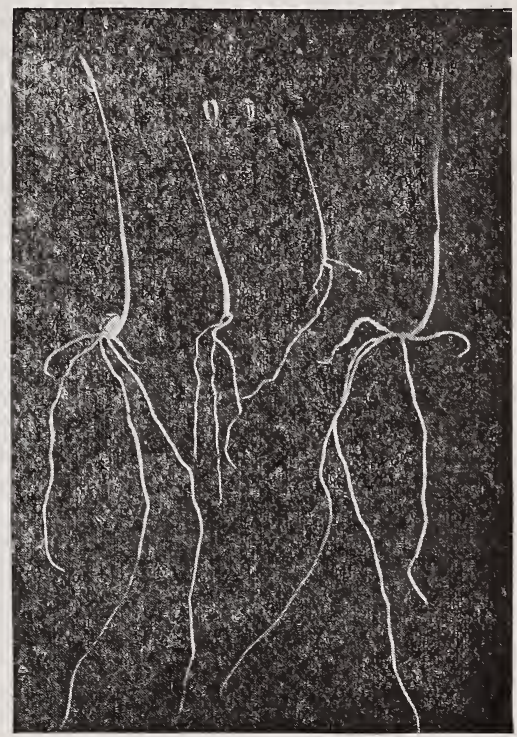

Cut shows plants produced from plump kernels compared to those grown from small shriveled kernels.

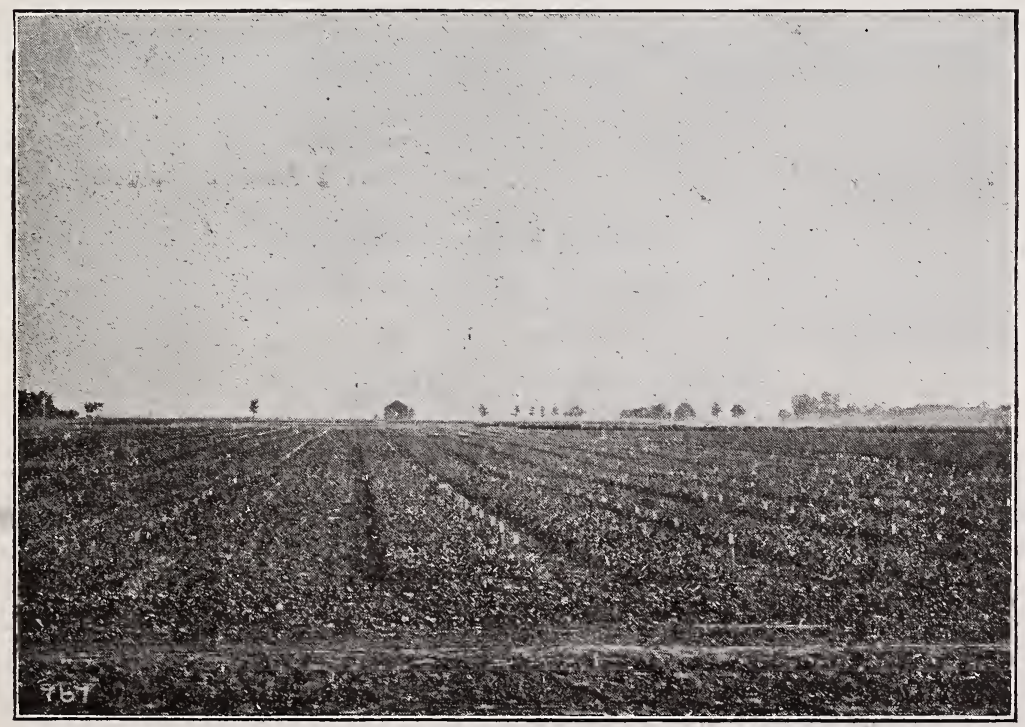

Cut Showing Method of Breeding Wheat. 


\section{Minnesota No. 169 Wheat.}

Minnesota No. 169 wheat was distributed by the Hinnesota experimental station in 1902. ten years after it was started from a single seed of blue stem wheat. It had been increased at university farm to 1,500 bushels. This was offered in lots of four bushels at $\$ 1.50$ per bushel, by private letter to 1,300 recommended farmers distributed in the varinus connties of the state, 376 purchased it. At the end of the threshing season in answer to a letter of inquiry, most of these cooperators reported their yields to the experimental station and sønt samples of the crop. These reports were carefully assorted and it was found that 89 of these farmers had reported this wheat sown at the same time, on the same kind of soil, and in the same manner as the wheat commonly grown by them. The tables below. giving the yields of this wheat at University farm and on the farms of these 89 co-operators, show the records of yield on which the claims of this wheat are based:

TABLE III. Nimnesota No. 169 Compared with Its Parent Variety Through 11 Trials at Tniversity Farm.

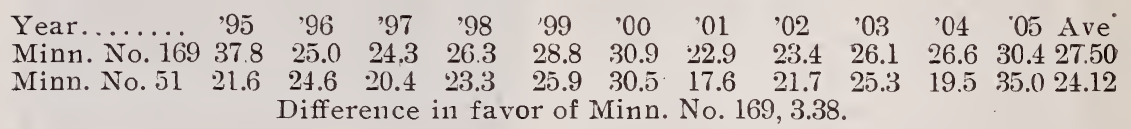

TABLE IV. Minn. No. 169 Compared with Common Wheat. Average of trials by 89 Farmers Throughout the State in 1902.

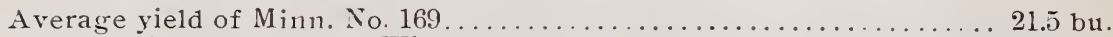

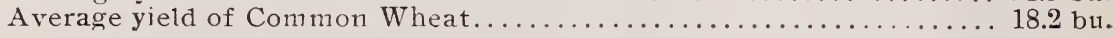

This variety was also tested as to its flour and bread making qualities with the assistance of Mr. C. E. Foster, at the same time as Minnesota No. 163 was tested. Recent tests made by Prof. Harry Snyder, also show this to be a very good quality of Blue Stem Wheat. It was found to have as good milling and baking qualities as i!s parent, a hard Blue Stem Wheat.

\section{Treat Your Wheat.}

All varieties of wheat are subject to smut, and all seed should be treated with formaldehyde, or, as it is sometimes called, formaline. Make a solution of one pound of formaldehyde, 40 per cent test, in forty-five gallons of water and sprinkle enough on the wheat to moisten it. Shovel over until dried, or sow after a few hours, opening the seeder to sow several quarts more per acre of the swollen sped. The cost of the medicine and labor is so slight, only about three cents per acre, that whoever sends smutty wheat to the market is advertising that he is a negligent farmer. 


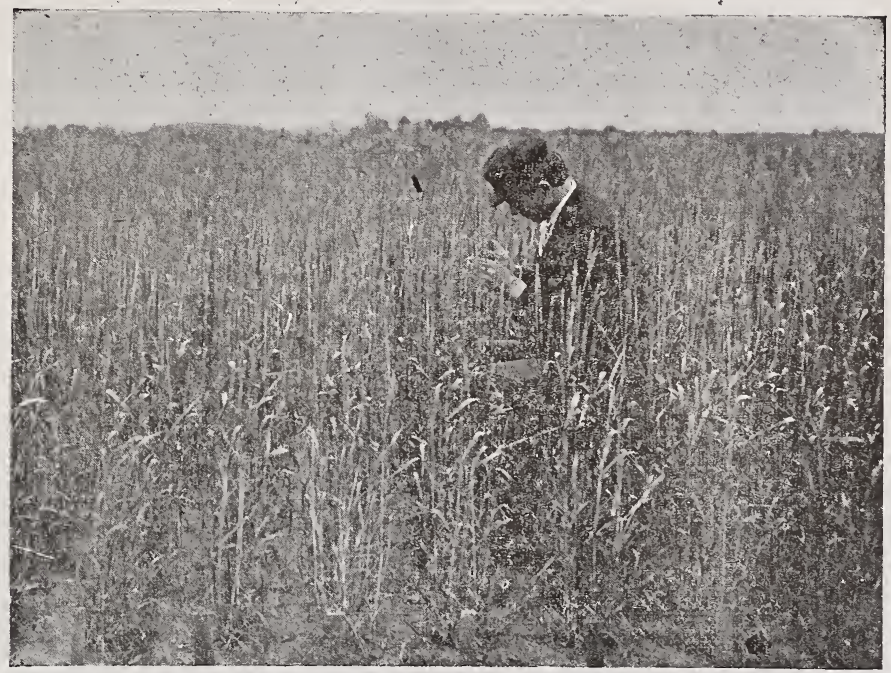

Originating New Varieties of Wheat at Minnesota Experimental Station.

\section{FORAGE PLANTS}

\section{EARLY AMBER CANE}

Seed for Fodder. Will produce aii abundance of feed per acre, which cortains much food value. Price per $100 \mathrm{lbs}$. Lags included $\$ 1.75$

\section{KAFFAR CORN}

Another forage plant used extensively in the middle west. Can be handled like millet. Price per $100 \mathrm{lbs}$., bags included.......\$1.50

\section{RAPE (Dwarf Essex)}

This plant is used extensively for sowing with grain in the spring for fall pasturnge. It makes very economical feed for sheep, hogs and cattle. Price per lb. 6c. Per 100 lbs...............\$5.75 


\section{SEED OATS}

\section{Minnesota Experimental Station No. 6 Oats.}

Too much attention cannot be given to the matter of procuring good seed, not only as to yield but to quality. The new No. 6 oats is a good yielder and is very plump having a large grain with thin hull. See illustration No 6 and the table below showing a comparison. This seed has been bred with a view of securing an oat with a stiff straw capable of keeping upright on all kinds of soil and producing a good yield. In this No. 6 oats both these qualities are found. In seeding oats the various conditions of the seed and soil should be taken into consideration to determine the amount of seed to be sown per acre. From $2 \frac{1}{2}$ to 3 bushels being the usual quantity required.

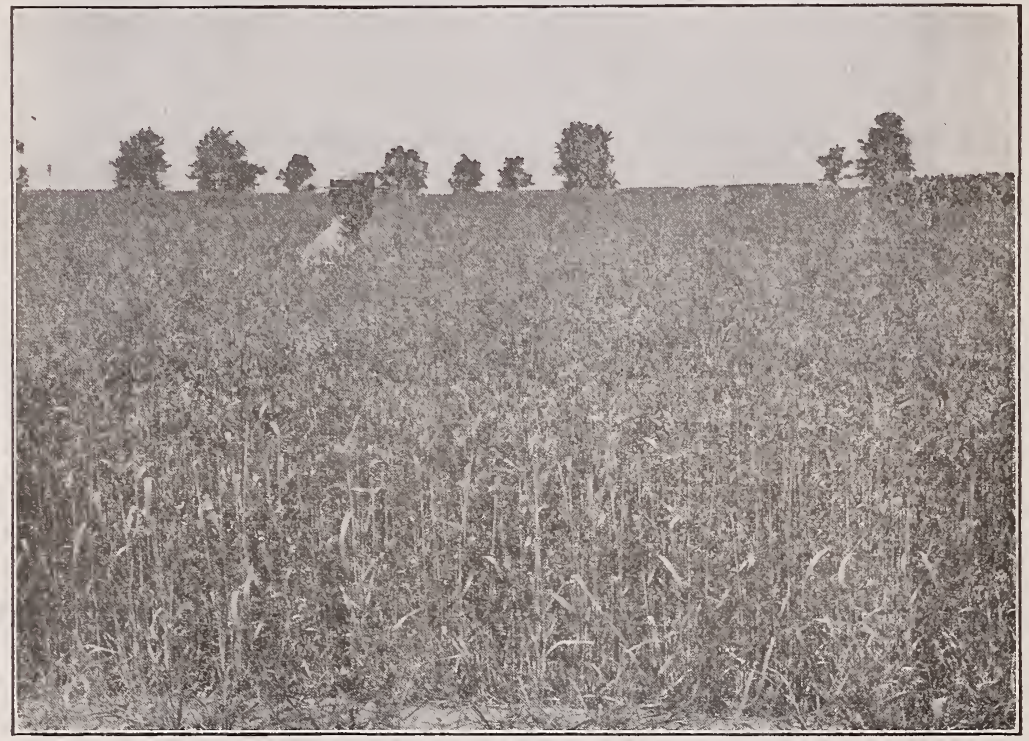

Cut Showing a Field of New No. 6 Oats. kind:

Table showing a ten year's yields of our No. 6 oats compared with ordinary

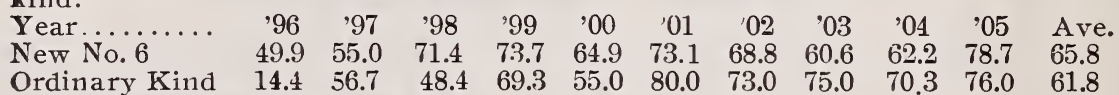

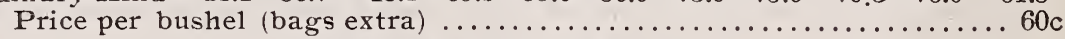

\section{Flax Seed.}

This year for the first time we offer PREMOST or Minnesota No. 25 Flax. Its superior yielding qualities is demonstrated in the accompanying table. It shows that the average yield for three years is 193 bushels while three common kinds during the same time averaged 15.9 bushels, a difference of 3.4 bushels or an increase in favor of Minn. No. 25 of 20 per cent. Our stock is limited, although we carry other varieties. Price per bushel .............. $\$ 2.25$

Have a stock of recleaned No. 1 seed $\mid$ Year........... '02 '03 '04

that has made excellent yields in the Minn. No. 25, Premost 21.4 $19.3 \quad 17.1$ past. Parties wanting a new strain $\begin{array}{llll}\text { Common kind } & 11,4 & 19.1 & 18.4\end{array}$ \begin{tabular}{ll|lll} 
of flax seed that is a good yielder will & Common kind & 12.5 & 20.3 & 13.4
\end{tabular} bushel (bags extra)...........\$1.40 Common kind $\quad 9.6 \quad 20.0 \quad 16.6$ 


\section{SEED BARLEY}

\section{Minnesota No. 105 Barley.}

In producing this barley the Experimental station realized the need of a variety which would have sufficiently stiff straw to stand upright on rich soils and moist weather. No. 105 barley has this quality to a marked degree and produces a good yield of plump grains.

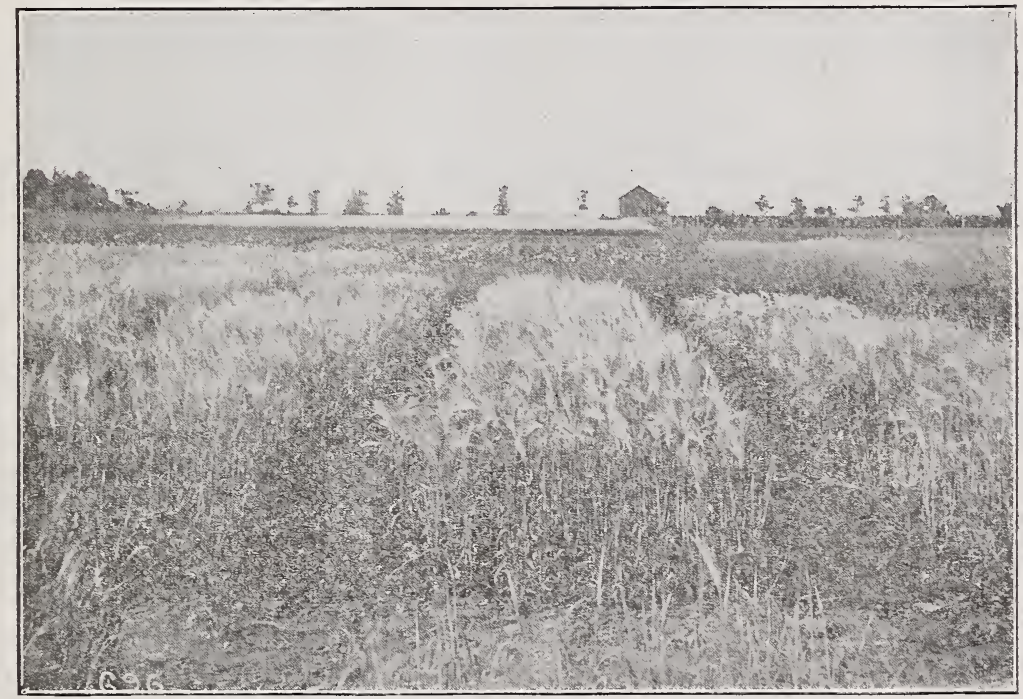

Cut Showing How Our Minnesota No. 105 Barley is Bred and is the Best Yielding Seed on the Market.

The following table compares Minn. No. 105 with common seed:

$\begin{array}{lcccccccc}\text { Year.......... } & \text { 99 } & 00 & \text { '01 } & \text { '02 } & \text { '03 } & \text { '04 } & \text { '05 } & \text { Ave. } \\ \text { Minn. No. 105 } & 62.6 & 53.3 & 60.0 & 58.1 & 485 & 44.8 & 54.4 & 54.5 \\ \text { Minn. No.100 } & 67.0 & 53.7 & 51.7 & 58.6 & 51.1 & 43.0 & 43.7 & 52.7\end{array}$

Price per bushel (bags extra) ........................... 85 c Write for prices on larger quantities of barley.

\section{Hanna Barley.}

This new barley was introduced by the Dept. of Agriculture and was brought from Austri? where it is famous for malting value and also its yielding qualities. It is a two rowed barley and has a very thin hull and plump kernel. This barley promises to become one of the most popular varieties grown. Price per pushel (bags extra) ........................\$1.00

Field Peas.

These are the genuine Canada field peas. Suitable for hog pastures. Price perbushel (bags extra) $\$ 1.75$

\section{Emmer or Spelz.}

즐

A new grain recently introduced from Russia. Makes an excellent food for any kind of stock. Yields well and will ripen in about the time required to mature barley. Price per bushel (bags extra) $75 \mathrm{c}$ 


\section{Seed Millet}

As a forage plant, millet is getting more popular each year. Mil. let should be sown at the rate of 35 to 40 lbs. per acre. When sown for seed a lesser quantity may be used. Can be sown any time after danger of frost in the spring and the Siberian as late as July 15th. Care should be taken not to plant too deep, as often deep planting is the cause of seed not sprouting.

New Siberian Millet. This new millet is very popular with those who have tried it. l'he seed is red and kernels very small. This must not be confounded with a variety called hy some Silerian or Russian millet, having a kernel about the size of broom corn millet. It has numerous and broad leaves while the stalk does not grow coarse and woody as with other millet. It is the earliest variety of millet. Price per bushel (bags extra)..................... 80 c

German Millet. (Southern grown seed.) Valuable as a forage plant. Price per bushel (bags extra) ................ 1

Common Millet. Northern grown German Millet. Price

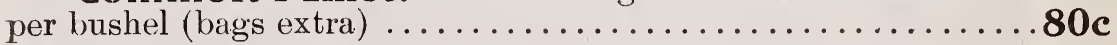

Hungarian Millet. (Dark Seed.) A well known seed valmable for hay. Price per bushel (bags extra)..........\$1.25

\section{Grass Seeds}

Have a complete stock of grass seeds for all kinds of soils. If parties wishing to seed large quantities of grass seed, and want mixtures, will write and state acreage and kind and condition of soil, we will send estimated cost of mixture, and most suitable.

In buying grass and clover seed it isour aim to procure seed grown as far north as possible. For instance clover seed bought on the Chicago or Toledo market, grown where the winters are not so severe and often open, could hardly be expected to thrive in a climate like this.

\section{CLOVERS}

\section{Medium Red}

Our stock of this seed is guaranteed to be Minnesota Grown seed, and is a fair quality grown in one of the best sections of the state. It is thoroughly cleaned. In planting this seed you will be absolutely safe in gretting a seed that is climated to wis state and will withstand the winter season. late seed for one acre. 


\section{Alsyke Clover}

This is a hardier clover and will withstand more moisture than the Medium Red, but does not grow as high, produces finer quality of hay. Guaranteed Minnesota grown seed. Required less seed per acre as the seeds are smaller. Price per pound............15c Per 100 lbs. (bags extra)... \$ \$14.õ 0

\section{White Clover}

Suitable for pasture mixtures and lawns. Grows very low and will spread rapidly even when sown in sud. Price per pound (bags extra ) ................20c

\section{Alfalfa Clover}

This plant has not generally been considered as adapted to this climate but has been grown successfully in parts of the state for years past in limited areas. We have secured a limited quantity of this seed grown in a section of the state where it has succeeded and consequently is thoronghly climated. Farmers wishing to give this most valuable forage plant a trial will find this seed much more apt to thrive than would seed brought from irrigated or southern sections. Price per pound....25c Per 100 llos. (bags extra) . . \$18.00 American grown, per pound. . 20c American grown, per 100 lbs. $\$ 16.00$

\section{TIMOTHY}

Minnesota grown seed recleaned on special crass seed cleaner. Fine quality of bright. seed free from all light and foreign seeds. You will find this seed much cheaper than to sow seed which has not been properly cleaned or contains foul seeds. Best quality, per bu. (bags extra) $\$ 1.50 \quad 100$ lbs. $\$ 3.2$ a

Seconrl quality per bushel 1.25 Per 100 lbs............. 2.75

\section{BROMUS INERMIS}

New irrass, suitable for high dry soil. 'I his grass produces best stand when sown without a nurse crop, on well prepared soil, and by keeping wee s inowed untill grass. gets a start. Can be used in grass seed mixture. 15 to 20 lbs. usually sown per acre. Best quality per 100 lbs. (bags extra) ..... \$12.00 Second quality, per 100 lbs. 10.00

25 and $50 \mathrm{lbs}$. at same rate.

\section{RYE GRASS}

Italian or Perennial, either is an excellent grass for pasture mixture. Per bu. of 14 lbs. (hags extra) 85c Per 100 pounds ......... $\$ 6.00$.

\section{ORCHARD GRASS}

A variety that will grow in shaded locations, suitable for pasturage in timber land, though it thrives on prairie land as well. Per bu. $\$ 1.90$ Per 100 lbs. (bags extra)... \$13.00

\section{KENTUCKY BLUEGRASS}

Fancy cleaned, suitable for medium and high well drained soils, either for meadow or pasture mixtures. Best quality per bu. $\$ 1.50$ Per 100 lbs. (bags extra) .. . 11.00

\section{RED TOP}

Solid, choice seed, suitable for medium or low locations, either for hay or for pasture mixtures. Per bu. of 14 lbs......... $\$ 1.20$ Pér 100 lbs. (bags extra).... 8.50

\section{CANADA BLUEGRASS}

For pasture mixtures, per lb.. To Per 100 lbs. (bags extra)....\$5.00

\section{ENGLISH BLUEGRASS}

For pasture mixtures, per lb.. To Per 100 lbs. (hags extra)...\$6.00

\section{PASTURE MIXTURES}

We will seud you a grass seed mixture for either high or low, light or heary soils. Write for prices stating kitid of soil. 


\section{Garden Seeds}

We offer garden seed in bulk of the varieties'listed below. These are the varieties commonly used and our customers will find them EIRST Class Seed at about half the prices ordinarily charged by catalogue houses.

These prices are for seeds packed but not delivered. If you wish the order sent by mail add 1 cent for each two ounces of seed.

In the absence of mstructions we will ship either by freight or express, at buyers expense.

\section{BEANS}

GOLDEN WAX and Black Wax, popular variety to use, Golden yellow pods,

Per lb $15 \mathrm{c} \quad 10 \mathrm{lbs}$ or more $12 \mathrm{c}$ LONG YELLOW, SIS WEEKS,

An early production, flat poded rariety,

Per lb 1 ác 10 lbs or more 12 . KIDNEY WAX,

as early as Golden ITax, fine flaror,

Per lb 20c 10 lbs or more $18 \mathrm{c}$

\section{BEETS}

LONG SMO,TH BLOOD.

The old fashioned garden beet.

\section{EARLY BLOOD TCBNIP.} matures early; especially fine table beet.

\section{HALF LON ( BLOOD,} fine beet for fall or winter use.

Per ounce כ̌c

\section{CABBAGE}

EARLI JER 'I IT AEFIELD, Very best early variety.

EARLI WLAT DTSCH.

Another excellent early kind.

\section{LARGE IATE DRUNHEAD,}

f(s) late and winter use.

Per ounce $10 \mathrm{c} \quad \frac{1}{2}$ pound $70 \mathrm{c}$

\section{CARROTS}

OXHEAliT.

Early table carrot, easily grown.

DANTERS HALF LONG, one of the most popular varieties. makes good yields.

IMPR()TED L'MNG ORANGE, can be grown for garden or tield use, fine for winter use,

Per ounce ว̃c Per pound $50 \mathrm{c}$

\section{CELERY}

\section{MUST POPCLAR TARIETY} grown by gardeners, easily bleached,

Per ounce 10c

$\frac{1}{3}$ pound $75 \mathrm{c}$ 


\section{GARDEN SEEDS, Continued}

\section{CUCUMBERS}

GREEN PROLIFIC,

one of the best pickling cucumbers.

IMPROVED LONG GREEN, standard sort for large fruit. Per ounce 5o Per pound 750

\section{LETTUCE}

BLACK SEEDED $\triangle I M P S O N$,

Large curled variety, does not toughen.

DENTER MARKET.

an early rariets head lettuce Per ounce j̃c Per pound 75c

\section{MANGELS}

GULDEN TANKARD.

Best known rariety

for stock.

YELLO II GLOBE,

for stock, very prolific.

Per lb 15c $10 \mathrm{lbs}$ or more $14 \mathrm{c}$

\section{MUSK MELONS}

OSAGE,

best known variety. dark

green color and netted,

PACL ROSE,

very sweet fine flavor,

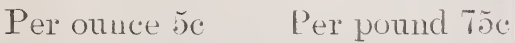

\section{ONIONS}

LARGE REI) WEI'HERSFI'LD standard variety, hardy, large croper,

Per ounce $10 \mathrm{c}$ Per pound $\$ 1.50$
ONIONS

YELLOW GLOBE DAN VERS,

Round, yellow skin, white

flesh, mild, good keeper,

Per ounce 10c Per pound $\$ 1.50$

AUSIRALIAN BROWN,

early ripening, medium size,

Per ounce 10c Per pound $\$ 1.25$

PUMPKIN

CONNECTICUT FIELD,

common kind grown for

stock. Jarge yielder.

Per lo $20 \mathrm{c} \quad 10$ lhs or more $18 \mathrm{c}$

PEAS

AMELICAN WUNDER,

the best knomn dwarf gar-

den pea. neeuls no support,

fine flaror.

Per pound 10e Per bu. $\$ 5.75$

ALASKA,

one of the earliest dwarf

peas. pods ripen quickly,

must be sown frequently

for table use,

HORSFORD MARKET

GARDEN. a good

wrinkle l variety,

Per 1h 10c Per bushel \$3.50

\section{RADISHES}

FRENCH BRE.AKFAS'T,

the stanclard sort for first

table use. scarlet color shad-

ing to white, olive shape,

Per ounce jc $\quad$ Per pound 50c 


\section{GARDEN SEEDS, Continued}

\section{RADISHES}

LONG BRIGHT SCARLET, long slender roots, fine talle radish,

MAMMOTH IVHITE.

solid and large, roots

8 to 10 inches long,

Per ounce 5c Per pound 50c

\section{RUTABAGA}

AMERICAN PURPLE TOP, best known sort for table use or stock, thrive well on new soil,

Per ounce 5c . Per pound $35 \mathrm{c}$

\section{SWEET CORN}

STOWELL'S EVERGREEN, best late and canning sweet corn on the market, produces large yields,

EARLY MINNESOTA, one of the best early corns for table use,

\section{EARLY COREY,}

for table use or canning,

Per pound 10c Per bushel $\$ 2.25$

\section{SQUASH}

\section{HUBBARD,}

warty, best known table squish, good yielder,

Per ounce je Per pound 70c

\section{SUGAR BEET}

VILMORIN,

originated by best grower

in France where sugar

beet is at home, fine

for stock,

Per lb 25c 10 lbs or more 20c

\section{TOMATOES}

ACME,

one of the best and earliest varieties, medium size fruit, PERFECIIION,

deep red in color, large size, perfectly smooth and solid, Per ounce $10 \mathrm{c}$ Per pound $\$ 1.50$

\section{TURNIPS}

WHITE GLOBE,

excellent for early garden, STRAP LEAF,

for garden or stock,

Per ounce 5c Per pound 35̌c

\section{WATER MELONS}

\section{CUBAAN QUEEN,}

best known, solid large,

PEERLESS',

medium size, thin rind,

light mottled green,

Per ounce 5c Per pound 60c 

tageporict

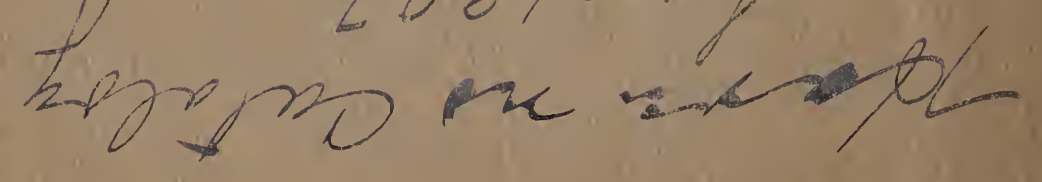

